\title{
Chitinophaga terrae sp. nov., isolated from soil
}

Correspondence Hee-Young Jung heeyoung@knu.ac.kr
Myung Kyum Kim ${ }^{1,2}$ and Hee-Young Jung ${ }^{1}$

\author{
${ }^{1}$ Division of Applied Biology and Chemistry, College of Agriculture and Life Sciences, Kyungpook \\ National University, Daegu, South Korea \\ ${ }^{2}$ Department of Oriental Medicinal Material and Processing, College of Life Sciences, Kyung Hee \\ University, Kyunggi-do, South Korea
}

The genus Chitinophaga, the type species of which is Chitinophaga pinensis, was first described by Sangkhobol \& Skerman (1981) as including strains of filamentous, chitinolytic, gliding bacteria that transform, upon ageing, into spherical bodies. Recently, Kämpfer et al. (2006) proposed five more Chitinophaga species by reclassifying [Cytophaga] arvensicola, [Flexibacter] filiformis, [Flexibacter] japonensis and [Flexibacter] sancti into the genus Chitinophaga, and by proposing Chitinophaga skermanii. At the time of writing, there are six Chitinophaga species with validly published names.

Strain $\mathrm{KPO1}^{\mathrm{T}}$ was originally isolated from soil from a field in Daejeon in South Korea. This soil sample was thoroughly suspended with $50 \mathrm{mM}$ phosphate buffer ( $\mathrm{pH}$ 7.0) and the suspension was spread on one-tenthstrength R2A agar (Difco) plates after serial dilution with $50 \mathrm{mM}$ phosphate buffer ( $\mathrm{pH} 7.0)$. The plates were incubated at $30{ }^{\circ} \mathrm{C}$ for 1 week. Single colonies were purified by transferring them onto new plates and were incubated once again, on full-strength R2A or Luria-Bertani (LB) agar (Difco) plates. Purified colonies were tentatively identified on the basis of partial sequences of the 16S rRNA gene (Im et al., 2005). They were routinely cultured on LB agar at $30{ }^{\circ} \mathrm{C}$ and maintained as a glycerol suspension $(20 \%$, w/v) at $-70{ }^{\circ} \mathrm{C}$.

A Gram reaction was performed using the non-staining method, as described by Buck (1982). Cell morphology was

The GenBank/EMBL/DDBJ accession number for the 16S rRNA gene sequence of strain $\mathrm{KPO}^{\top}$ is $\mathrm{AB} 278570$. observed under a Nikon light microscope at $\times 1000$, with cells grown for 3 days at $30^{\circ} \mathrm{C}$ on LB agar. Catalase activity was determined by assessing bubble production in $3 \%$ (v/v) $\mathrm{H}_{2} \mathrm{O}_{2}$, and oxidase activity was determined using $1 \%$ $(\mathrm{w} / \mathrm{v})$ tetramethyl-p-phenylenediamine. Carbon-source utilization and enzyme activities were tested by using API 20NE, API ID 32 GN and API ZYM test kits (bioMérieux). Growth at different temperatures $(4,15,20,25,30,37$ and $42{ }^{\circ} \mathrm{C}$ ) and various $\mathrm{pH}$ values $(\mathrm{pH} 5.0-11.0$ at intervals of $0.5 \mathrm{pH}$ units) was assessed after 5 days incubation. Growth on nutrient agar and trypticase soy agar (Difco) was also evaluated at $30{ }^{\circ} \mathrm{C}$.

Extraction of genomic DNA was performed with a commercial genomic DNA-extraction kit (Solgent). PCRmediated amplification of the $16 \mathrm{~S}$ rRNA gene and sequencing of the purified PCR product were carried out according to Kim et al. (2005). Full sequences of the 16S rRNA gene were compiled using SeqMan software (DNASTAR). The 16S rRNA gene sequences of related taxa were obtained from GenBank. Multiple alignments were performed with the CLUSTAL_X program (Thompson et al., 1997), gaps were edited in the BioEdit program (Hall, 1999) and evolutionary distances were calculated using the Kimura twoparameter model (Kimura, 1983). Phylogenetic trees were constructed using the neighbour-joining method (Saitou \& Nei, 1987) with the MEGA3 program (Kumar et al., 2004); bootstrap percentages were based on 1000 replications (Felsenstein, 1985).

For the measurement of the $\mathrm{G}+\mathrm{C}$ content of the chromosomal DNA, genomic DNA of the novel strain was 
Table 1. Phenotypic characteristics of strain $\mathrm{KPO}^{\top}$ and type strains of related Chitinophaga species

Strains: $1, \mathrm{KP}^{\mathrm{T}} \mathrm{1}^{\mathrm{T}}$ (data from this study); 2, C. arvensicola IAM $12650^{\mathrm{T}}$; 3, C. filiformis NBRC $15056^{\mathrm{T}}$; 4, C. japonensis NBRC $16041^{\mathrm{T}}$; 5, C. pinensis ACM $2034^{\mathrm{T}}$; 6, C. sancti NBRC $15057^{\mathrm{T}}$; 7, C. skermanii CC-SG1B ${ }^{\mathrm{T}}$. Data for reference strains are from Kämpfer et al. (2006). All of the strains were Gram-negative and isolated from soil. All utilize maltose and D-mannose. +, Positive; -, negative; ND, not determined.

\begin{tabular}{|c|c|c|c|c|c|c|c|}
\hline Characteristic & 1 & 2 & 3 & 4 & 5 & 6 & 7 \\
\hline Gliding motility & - & - & + & + & + & + & - \\
\hline Cell length $(\mu \mathrm{m})$ & $0.6-0.8$ & $0.6-4$ & $30-80$ & $2-18$ & $<40$ & $2-15$ & $1-2$ \\
\hline Colony colour & Yellow & Yellow-orange & Golden yellow & Yellow-orange & Yellow & Golden yellow & Yellow \\
\hline Oxidase & + & + & + & + & + & ND & + \\
\hline Catalase & + & + & - & + & + & - & + \\
\hline Growth at $37{ }^{\circ} \mathrm{C}$ & + & - & + & + & + & - & + \\
\hline Chitinase & - & - & + & - & + & - & $\mathrm{ND}$ \\
\hline Gelatin hydrolysis & - & - & + & + & + & + & + \\
\hline Urease & - & - & $\mathrm{ND}$ & $\mathrm{ND}$ & + & $\mathrm{ND}$ & - \\
\hline \multicolumn{8}{|l|}{ Assimilation of: } \\
\hline Gluconate & - & - & - & - & - & + & - \\
\hline L-Arabinose & + & + & - & + & + & + & - \\
\hline D-Melibiose & + & + & + & + & - & + & + \\
\hline L-Rhamnose & + & + & - & + & + & - & - \\
\hline D-Ribose & - & + & - & - & - & - & - \\
\hline Sucrose & + & + & + & + & + & - & - \\
\hline Inositol & - & - & - & - & - & - & - \\
\hline $\mathrm{N}$-Acetylglucosamine & + & + & - & + & + & - & + \\
\hline Salicin & + & + & + & + & + & - & + \\
\hline DNA G $+C$ content $(\mathrm{mol} \%)$ & 46.3 & 46.0 & 45.0 & 49.8 & 45.2 & 43.3 & 40.7 \\
\hline
\end{tabular}

extracted and purified as described by Moore \& Dowhan (1995) and enzymically degraded into nucleosides and the $\mathrm{G}+\mathrm{C}$ content was determined as described by Mesbah et al. (1989) using reversed-phase HPLC. Isoprenoid quinones were extracted with chloroform/methanol $(2: 1, \mathrm{v} / \mathrm{v})$, evaporated under vacuum conditions and re-extracted in n-hexane/water $(1: 1, \mathrm{v} / \mathrm{v})$. The crude $\mathrm{n}$-hexane-quinone solution was purified using Sep-Pak Vac silica cartridges (Waters) and subsequently analysed by HPLC as described previously (Hiraishi et al., 1996). Cellular fatty acid profiles were determined for strains grown on trypticase soy agar at $30{ }^{\circ} \mathrm{C}$ for 2 days. The cellular fatty acids were saponified, methylated and extracted according to the protocol of the Sherlock Microbial Identification System (MIDI). The fatty acids were analysed by gas chromatography (6890; Hewlett Packard) and identified using the Microbial Identification software package (Sasser, 1990).

Strain $\mathrm{KP}^{\mathrm{T}} \mathrm{T}^{\mathrm{T}}$ was found to comprise Gram-negative, aerobic, non-motile, non-spore-forming rods. Colonies grown on LB agar plates for 3 days were smooth, circular and yellowish. The strain grew well on nutrient agar, trypticase soy agar and LB agar. The physiological characteristics of strain $\mathrm{KP}^{\mathrm{T}} 1^{\mathrm{T}}$ are summarized in the

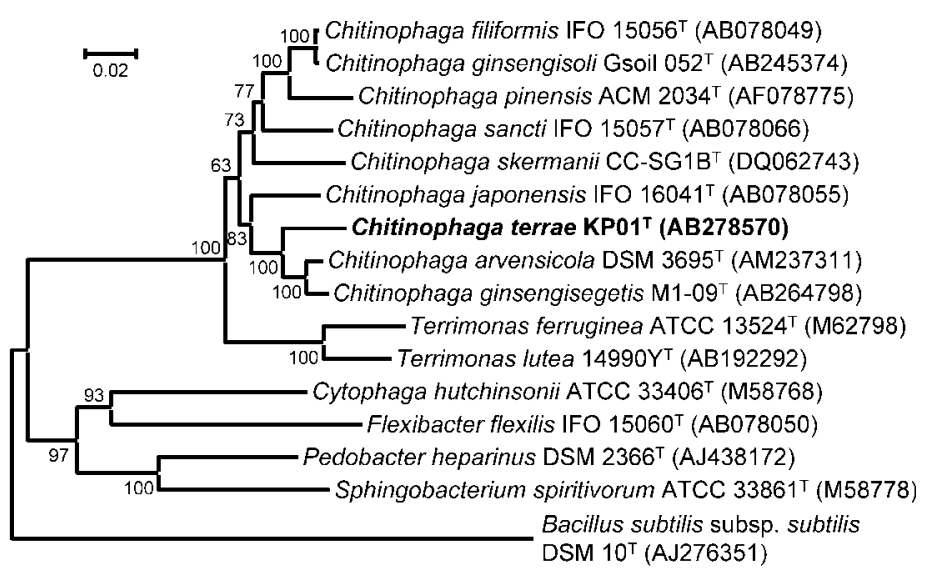

Fig. 1. Phylogenetic tree, constructed from a comparative analysis of $16 \mathrm{~S}$ rRNA gene sequences, showing the relationships of strain $\mathrm{KPO} 1^{\top}$ with related species. This tree was constructed using the neighbour-joining method (Saitou \& Nei, 1987) with Kimura's twoparameter distance matrix (Kimura, 1983) and pairwise deletion. Bootstrap percentages are based on 1000 replications. Bar, 0.02 substitutions per nucleotide position. 
species description, and differential characteristics are compared with those of Chitinophaga species in Table 1.

An almost-complete 16S rRNA gene sequence (1478 bp) for strain $\mathrm{KP}^{\mathrm{T}} \mathrm{1}^{\mathrm{T}}$ was determined and subjected to a comparative analysis. A phylogenetic analysis based on $16 \mathrm{~S}$ rRNA gene sequences indicated that strain $\mathrm{KP}^{\mathrm{T}}{ }^{\mathrm{T}}$ belongs to the genus Chitinophaga (Fig. 1), but the 16S rRNA gene sequence similarity with respect to the most closely related Chitinophaga species was $95.7 \%$, suggesting that it is different at the species level (Stackebrandt \& Goebel, 1994). Strain $\mathrm{KP} 01^{\mathrm{T}}$ showed the highest level of $16 \mathrm{~S}$ rRNA gene sequence similarity with respect to $C$. arvensicola IAM $12650^{\mathrm{T}}(95.7 \%)$, followed by Chitinophaga ginsengisegetis M1-09 $9^{\mathrm{T}}(95.6 \%)$, Chitinophaga japonensis IFO $16041^{\mathrm{T}}$ (93.3\%), Chitinophaga sancti IFO $15057^{\mathrm{T}}(92.7 \%)$, Chitinophaga filiformis IFO $15056^{\mathrm{T}}$ (91.9\%), Chitinophaga ginsengisoli Gsoil $052^{\mathrm{T}}$ (91.9\%), C. skermanii SG-1B (91.7\%), C. pinensis ACM $2034^{\mathrm{T}}(90.3 \%)$ and Terrimonas lutea $14990 \mathrm{Y}^{\mathrm{T}}(90.4 \%)$. These values $(<97 \%)$ were low enough, according to Stackebrandt \& Goebel (1994), to justify the placement of strain $\mathrm{KP} 1^{\mathrm{T}}$ as a novel species within the genus Chitinophaga.

The DNA G $+\mathrm{C}$ content of strain $\mathrm{KP} 01^{\mathrm{T}}$ was $46.3 \mathrm{~mol} \%$. The major respiratory quinone was MK-7, as is the case for the known species of the genus Chitinophaga (Kämpfer et al., 2006). The major fatty acids of the strain were $C_{15: 0}$ iso, $\mathrm{C}_{16: 1} \omega 5 c$ and hydroxy fatty acid $\mathrm{C}_{17: 0}$ iso $3-\mathrm{OH}$, as shown in Table 2; this profile is consistent with those of known Chitinophaga species (Kämpfer et al., 2006). Minor amounts of saturated fatty acids $\mathrm{C}_{14: 0}(0.9 \%), \mathrm{C}_{15: 0}$ iso $3-\mathrm{OH}(3.4 \%), \mathrm{C}_{16: 0} 3-\mathrm{OH}(3.0 \%), \mathrm{C}_{17: 0}$ iso $(1.0 \%)$ and summed features $3\left(\mathrm{C}_{16: 1} \omega 7 c / \mathrm{C}_{15: 0}\right.$ iso $\left.2-\mathrm{OH}\right)(3.0 \%)$ and $4\left(\mathrm{C}_{17: 1}\right.$ iso $\mathrm{I} / \mathrm{C}_{17: 1}$ anteiso $\left.\mathrm{B}\right)(1.0 \%)$ were present.

On the basis of the data and observations described above, strain $\mathrm{KP} 1^{\mathrm{T}}$ should be assigned to the genus Chitinophaga as the type strain of a novel species, for which the name Chitinophaga terrae sp. nov. is proposed.

\section{Description of Chitinophaga terrae sp. nov.}

Chitinophaga terrae (ter'rae. L. gen. n. terrae of the earth).

Cells are Gram-negative, aerobic, non-motile rods that are $0.3-0.5 \mu \mathrm{m}$ in width and $0.6-0.8 \mu \mathrm{m}$ in length after 3 days culture on R2A agar. Colonies grown on LB agar for 3 days are smooth, circular, convex and yellowish. Grows at $15-42{ }^{\circ} \mathrm{C}$ and at $\mathrm{pH} 6.0-9.0$, but grows slowly at $42{ }^{\circ} \mathrm{C}$ and $\mathrm{pH}$ 9.0. Can reduce nitrate to nitrate but not to nitrogen gas. Enzyme activities, substrate assimilation and other physiological characteristics are indicated in Table 1 . Produces $N$-acetyl- $\beta$-glucosaminidase, acid phosphatase, alkaline phosphatase, $\alpha$-chymotrypsin, cystine arylamidase, esterase (C4), esterase (C8), $\alpha$-fucosidase, $\alpha$-galactosidase, $\alpha$-glucosidase, $\beta$-galactosidase, $\beta$-glucosidase, leucine arylamidase, $\alpha$-mannosidase, naphthol-ASBI-phosphohydrolase, trypsin and valine arylamidase. Does not produce arginine dihydrolase, $\beta$-glucuronidase, lipase
Table 2. Cellular fatty acid profiles of stain $\mathrm{KPO}^{\top}$ and type strains of related Chitinophaga species

Strains: $1, \mathrm{KP}^{\mathrm{T}}{ }^{\mathrm{T}}$ (data from this study); 2, C. arvensicola DSM $3695^{\mathrm{T}}$; 3, C. filiformis CCUG $12809^{\mathrm{T}}$; 4, C. japonensis DSM $13484^{\mathrm{T}}$; 5 , C. pinensis DSM $2588^{\mathrm{T}}$; 6 , C. sancti DSM $784^{\mathrm{T}}$; 7, C. skermanii CC$\mathrm{SG}^{\mathrm{T}}{ }^{\mathrm{T}}$. Data for reference strains are from Kämpfer et al. (2006). Major components are in bold.

\begin{tabular}{|c|c|c|c|c|c|c|c|}
\hline Fatty acid & 1 & 2 & 3 & 4 & 5 & 6 & 7 \\
\hline $\mathrm{C}_{14: 0}$ & 0.9 & 1.4 & 0.9 & 0.5 & 0.7 & 0.7 & 1.8 \\
\hline $\mathrm{C}_{15: 0}$ & & 0.4 & & & 0.4 & & 0.4 \\
\hline $\mathrm{C}_{15: 0} 2-\mathrm{OH}$ & & 0.3 & & & & & \\
\hline $\mathrm{C}_{15: 0}$ anteiso & & 0.6 & & 0.5 & & & \\
\hline $\mathrm{C}_{15: 0}$ iso & 42.2 & 35.3 & 37.3 & 40.0 & 30.4 & 44.0 & 47.3 \\
\hline $\mathrm{C}_{15: 0}$ iso $3-\mathrm{OH}$ & 3.4 & 3.0 & 3.3 & 2.4 & 3.1 & 3.4 & 2.6 \\
\hline $\mathrm{C}_{16: 0}$ & 3.2 & 5.1 & 4.3 & 3.0 & 4.2 & 4.2 & 3.5 \\
\hline $\mathrm{C}_{16: 0}$ 10-methyl & & 0.4 & & 0.9 & & & \\
\hline $\mathrm{C}_{16: 0} 2-\mathrm{OH}$ & & & 1.1 & 3.0 & 0.7 & 0.7 & \\
\hline $\mathrm{C}_{16: 0} 3-\mathrm{OH}$ & 3.0 & 1.7 & 1.2 & 0.8 & 1.2 & 0.5 & 1.6 \\
\hline $\mathrm{C}_{16: 0}$ iso & & 0.3 & & & & & \\
\hline $\mathrm{C}_{16: 0}$ iso $3-\mathrm{OH}$ & & 0.5 & & 0.4 & 0.4 & & 0.4 \\
\hline $\mathrm{C}_{16: 1} \omega 11 c$ & & 0.5 & & 1.0 & 1.9 & 0.9 & 0.4 \\
\hline $\mathrm{C}_{16: 1} \omega 5 c$ & 25.0 & 33.6 & 25.5 & 22.2 & 33.2 & 13.5 & 24.4 \\
\hline $\mathrm{C}_{17: 0} 2-\mathrm{OH}$ & & 0.4 & & 0.4 & & & \\
\hline $\mathrm{C}_{17: 0}$ anteiso & & & & 0.4 & & & \\
\hline $\mathrm{C}_{17: 0}$ iso & 1.0 & 0.4 & & 1.8 & 0.4 & 0.6 & 0.6 \\
\hline $\mathrm{C}_{17: 0}$ iso $3-\mathrm{OH}$ & 12.3 & 5.9 & 11.8 & 13.0 & 11.5 & 9.1 & 5.0 \\
\hline $\mathrm{C}_{17: 1}$ iso $\omega 9 c$ & & 0.3 & & & & 1.1 & \\
\hline \multicolumn{8}{|l|}{$\mathrm{C}_{18: 0}$} \\
\hline \multicolumn{8}{|l|}{$\mathrm{C}_{18: 3} \omega 6 c$} \\
\hline \multicolumn{8}{|l|}{ Summed features ${ }^{\star}$} \\
\hline 2 & & 0.4 & & 0.5 & & & 0.4 \\
\hline 3 & 3.0 & 3.7 & 11.2 & 3.3 & 7.7 & 16.0 & 3.5 \\
\hline 4 & 1.0 & & & 1.3 & & 0.8 & 0.4 \\
\hline \multicolumn{8}{|c|}{ Unknown fatty acids $\dagger$} \\
\hline ECL 11.543 & & 0.5 & & & & & 0.8 \\
\hline ECL 13.565 & 3.2 & 3.6 & 2.5 & 3.1 & 2.6 & 3.2 & 4.4 \\
\hline ECL 14.959 & & 0.3 & & & 0.3 & & 0.4 \\
\hline ECL 16.582 & 1.1 & 0.8 & 0.9 & 1.1 & 1.1 & 1.3 & 0.7 \\
\hline
\end{tabular}

${ }^{*}$ Summed feature 2 contains one or more of $\mathrm{C}_{12: 0}$ aldehyde, $\mathrm{C}_{14: 0}$ 3-OH and $\mathrm{C}_{16: 1}$ iso; summed feature 3 contains $\mathrm{C}_{16: 1} \omega 7 c$ and/or $\mathrm{C}_{15: 0}$ iso 2-OH; summed feature 4 contains $\mathrm{C}_{17: 1}$ iso $\mathrm{I}$ and/or $\mathrm{C}_{17: 1}$ anteiso $\mathrm{B}$.

$\dagger \mathrm{ECL}$, Equivalent chain length.

(C14), protease (gelatin hydrolysis) or urease. Assimilates L-arabinose, L-fucose, D-glucose, maltose, D-mannose, D-melibiose, L-rhamnose, sucrose, $\mathrm{N}$-acetyl-D-glucosamine and salicin. Does not assimilate acetate, adipate, caprate, citrate, gluconate, 3-hydroxybenzoate, 4-hydroxybenzoate, 3-hydroxybutyrate, itaconate, 2-ketogluconate, 5-ketogluconate, lactate, L-malate, malonate, phenylacetate, propionate, suberate, n-valerate, D-ribose, myo-inositol, D-mannitol, D-sorbitol, L-alanine, L-histidine, L-proline, L-serine or glycogen. MK-7 is the predominant menaquinone and $\mathrm{C}_{15: 0}$ iso, $\mathrm{C}_{16: 1} \omega 5 c$ and $\mathrm{C}_{17: 0}$ iso $3-\mathrm{OH}$ are the 
predominant cellular fatty acids. The $\mathrm{G}+\mathrm{C}$ content of the genomic DNA of the type strain is $46.3 \mathrm{~mol} \%$.

The type strain, $\mathrm{KP}^{2} 1^{\mathrm{T}}\left(=\mathrm{KCTC} 12836^{\mathrm{T}}=\mathrm{LMG} 24015^{\mathrm{T}}\right)$, was isolated from soil from a field near Daejeon, South Korea.

\section{References}

Buck, J. D. (1982). Nonstaining (KOH) method for determination of Gram reactions of marine bacteria. Appl Environ Microbiol 44, 992-993.

Felsenstein, J. (1985). Confidence limits on phylogenies: an approach using the bootstrap. Evolution 39, 783-791.

Hall, T. A. (1999). BioEdit: a user-friendly biological sequence alignment editor and analysis program for Windows 95/98/NT. Nucleic Acids Symp Ser 41, 95-98.

Hiraishi, A., Ueda, Y., Ishihara, J. \& Mori, T. (1996). Comparative lipoquinone analysis of influent sewage and activated sludge by highperformance liquid chromatography and photodiode array detection. J Gen Appl Microbiol 42, 457-469.

Im, W.-T., Jung, H.-M., Cui, Y.-S., Liu, Q.-M., Zhang, S.-L. \& Lee, S.-T. (2005). Cultivation of the three hundreds of bacterial species from soil of a ginseng field and mining the novel lineage bacteria. In Proceedings of the International Meeting of the Federation of Korean Microbiological Societies, abstract A035, p. 169. Seoul: Federation of Korean Microbiological Societies.

Kämpfer, P., Young, C. C., Sridhar, K. R., Arun, A. B., Lai, W. A., Shen, F. T. \& Rekha, P. D. (2006). Transfer of [Flexibacter] sancti, [Flexibacter] filiformis, [Flexibacter] japonensis, and [Cytophaga] arvensicola to the genus Chitinophaga and description of Chitinophaga skermanii sp. nov. Int J Syst Evol Microbiol 56, 2223-2228.
Kim, M. K., Im, W.-T., Ohta, H., Lee, M. \& Lee, S.-T. (2005). Sphingopyxis granuli sp. nov., a $\beta$-glucosidase-producing bacterium in the family Sphingomonadaceae in $\alpha-4$ subclass of the Proteobacteria. J Microbiol 43, 152-157.

Kimura, M. (1983). The Neutral Theory of Molecular Evolution. Cambridge: Cambridge University Press.

Kumar, S., Tamura, K. \& Nei, M. (2004). MEGA3: integrated software for molecular evolutionary genetics analysis and sequence alignment. Brief Bioinform 5, 150-163.

Mesbah, M., Premachandran, U. \& Whitman, W. B. (1989). Precise measurement of the $\mathrm{G}+\mathrm{C}$ content of deoxyribonucleic acid by highperformance liquid chromatography. Int J Syst Bacteriol 39, 159-167.

Moore, D. D. \& Dowhan, D. (1995). Preparation and analysis of DNA. In Current Protocols in Molecular Biology, pp. 2-11. Edited by F. M. Ausubel, R. Brent, R. E. Kingston, D. D. Moore, J. G. Seidman, J. A. Smith \& K. Struhl. New York: Wiley.

Saitou, N. \& Nei, M. (1987). The neighbor-joining method: a new method for reconstructing phylogenetic trees. Mol Biol Evol 4, 406-425.

Sangkhobol, V. \& Skerman, V. B. D. (1981). Chitinophaga, a new genus of chitinolytic myxobacteria. Int J Syst Bacteriol 31, 285-293.

Sasser, M. (1990). Identification of bacteria by gas chromatography of cellular fatty acids, MIDI Technical Note 101. Newark, DE: MIDI Inc.

Stackebrandt, E. \& Goebel, B. M. (1994). Taxonomic note: a place for DNA-DNA reassociation and 16S rRNA sequence analysis in the present species definition in bacteriology. Int J Syst Bacteriol 44, 846-849.

Thompson, J. D., Gibson, T. J., Plewniak, F., Jeanmougin, F. \& Higgins, D. G. (1997). The CLUSTAL_X windows interface: flexible strategies for multiple sequence alignment aided by quality analysis tools. Nucleic Acids Res 25, 4876-4882. 